\title{
When cycle paths are not enough: Seville's bicycle-PT project
}

\author{
R. Marqués ${ }^{1}$, V. Hernández-Herrador ${ }^{1}$, M. Calvo-Salazar ${ }^{2}$, \\ J. Herrera-Sánchez ${ }^{2} \&$ M. López-Peña ${ }^{2}$ \\ ${ }^{1}$ SIBUS, University of Seville, Spain \\ ${ }^{2}$ Private Consultants, Spain
}

\begin{abstract}
The city of Seville (Spain) has been named the fourth most "bicycle-friendly city" in the world, mainly due to the building of a segregated network of bicycle paths which, in a few years, substantially increased utilitarian cycling in the city. However, recent bicycle counts along the network have shown that the volume of cycling is now levelling off at around 6\% of the city's mobility $(9 \%$ of all mechanised trips); a meaningful level but still far from the figures that are usual in leading cycling cities. This stagnation suggests that new actions are needed in order to further develop urban cycling and overcome bottlenecks that prevent its growth, perhaps by integrating cycling policies into wider sustainable mobility and traffic calming policies. Among these actions, improving links between bicycles and public transport (PT) could play a significant role. This is the subject of the Bicycle-PT research project that is currently being developed by the authors at the University of Seville and founded by the Regional Government. The main aim of this project is to diagnose present links and to evaluate the potential market for bicycle-PT intermodality in the entire metropolitan area, as well as to make specific proposals for its development. For this purpose, the authors use a geographic information system (GIS) based methodology, combined with information provided by mobility and opinion surveys.

Keywords: bicycling, public transport, active mobility, sustainable transport, Sevilla (Seville), Spain.
\end{abstract}




\section{Introduction}

Bicycle promotion is now considered to be an important part of policies aimed at improving the sustainability of transport $[1,2]$. As a consequence, in recent years, infrastructure for utilitarian cycling has been increasingly improved in many cities and countries around the world [3]. An outstanding example of this tendency is the city of Seville (Spain), which has recently been named the fourth most bicycle-friendly city in the world [4]. This designation stems mainly from the building of a very complete network of cycle paths combined with a successful public bike-sharing scheme, which raised bicycle modal share from negligible values to $6 \%$ of all trips $[5,6]$.

However, in recent years, there has been a stagnation of the number of bicycle trips in the city, even though the network of cycling routes has continued to develop (see Figure 1). This suggests that in addition to the construction of bike paths, other initiatives could also be important in order to increase utilitarian cycling in the City. Among these initiatives there could be provision of parking spaces at the origin (households) and destination (shops, factories, schools...) of bike trips, as well as improved links between bicycles and public transport (PT) [6].

There is mounting evidence that improving links between bicycle and PT can have positive effects on both modes [1, 7-9]. Probably, the main benefit for PT comes from the extension of the catchment area of PT stations, up to a radius of approximately $3 \mathrm{~km}[1,10]$. Regarding cycling, it is well known that bicycles are competitive with cars for distances up to $5 \mathrm{~km}[1,2]$. For longer distances, linking with public transport becomes a good solution for many bicyclists.

Policies to promote links between bicycles and PT can be classified into two broad categories:

- Policies that promote the transport of bicycles in PT vehicles, or "bike on board" policies, and

- Policies that promote the parking and/or the loan of bicycles at PT stations.

The first kind of policy is very popular in North America, where transporting bikes on buses using front racks is widespread [11]. However, massive intermodality between bicycles and public transport usually needs massive parking infrastructure at PT stations, eventually combined with bike loan services and/or public bikes [11-14]. This last concept has recently evolved to the "Radstation" (bike station) concept [11]. Whatever the solution may be, any policy aimed at promoting links between bicycles and PT must include a diagnosis, an assessment of the potential market and demand and, if possible, pilot projects aimed at the verification of the hypothesis.

Links between bicycle and PT have been extensively studied [8-19]. Most of these analyses reveal that availability of infrastructures such as parking places at PT stations or cycle paths to access them has a positive effect on bicycle-PT intermodality, whereas car availability has a negative but moderate effect. On the other hand, Geographic Information Systems (GIS) have been extensively used 
for bicycle infrastructure analysis [20, 21], PT accessibility analysis [22] and, more recently, for the planning of bicycle and PT links [19].

In this paper, a GIS based methodology for the planning of links between bicycles and PT is presented. The main expected outcome of this methodology is an assessment of the potential demand for infrastructure such as bike parking and bike rental services at the different PT stations. This evaluation comes from the analysis of the catchment areas of these stations, the population living in these areas, the mobility of such population and the expected penetration of cycling in the modal share. Although this methodology has been developed for the city of Seville, the authors feel that it contains elements - such as the methodology for the determination of the catchment areas or the evaluation of the potential market of trips - that can be applied to other cities with similar characteristics.

The paper is organized as follows: In the next section a diagnosis of the current state of links between bicycles and PT in the city of Seville is presented. Next, the proposed methodology for the evaluation of the potential market and the expected demand for bicycle-PT intermodality is developed and applied to high capacity PT in the metropolitan area of Seville. Finally, some conclusions are put forward.

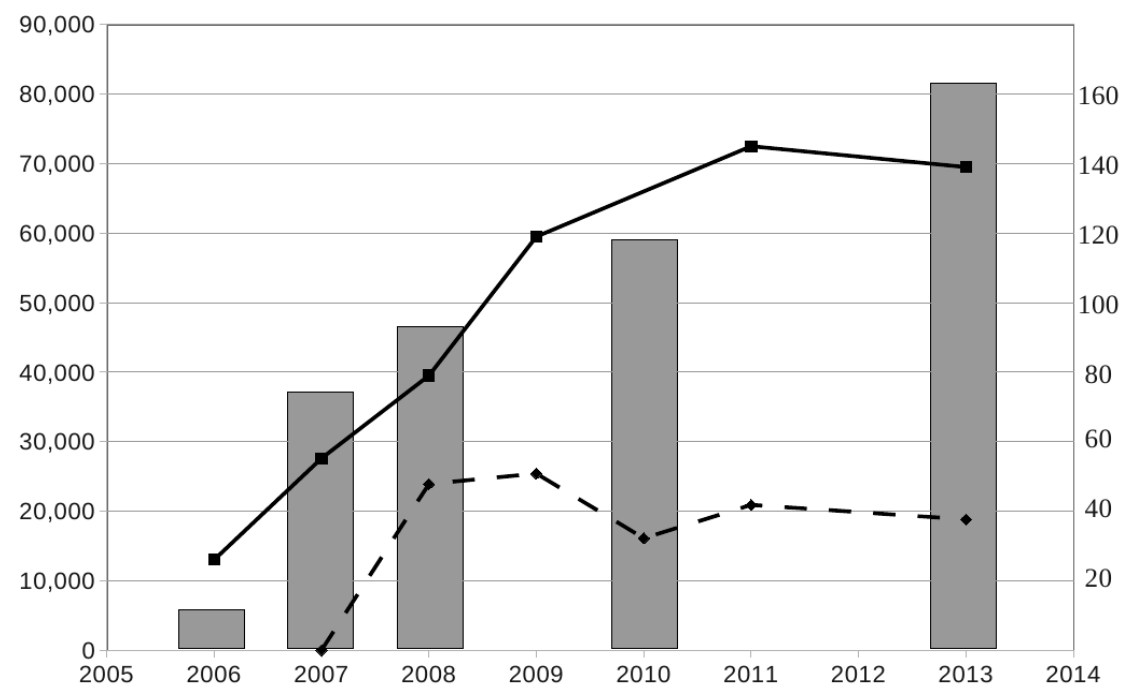

Figure 1: Evolution of the total number of daily bicycle trips (solid line), of the number of daily trips on public bikes (dashed line) and of the total $\mathrm{km}$ of cycle paths in the city of Seville (vertical bars, right scale). Source: compiled by the authors from data of the Municipality of Seville and from [6, 23, 24]. 


\section{Diagnosis}

Seville is a high-density city of 702,000 inhabitants, surrounded by a low density conurbation with approximately the same population. Per capita GDP is $€ 18,600$ and the number of car-free households is approximately $20 \%$ in the entire Metropolitan Region. Its flat terrain and dry weather favour cycling, except in summer, when temperatures are very high. Nevertheless, utilitarian cycling remained underdeveloped until very recently when, as can be seen in Fig. 1, in just five years the number of bicycle trips in the city experienced a sevenfold increase and cycling modal share reached $6 \%[5,6]$. However, it must be said that this experience was limited to the central area of the conurbation (i.e. the city of Seville), and had no effect on the surrounding metropolitan area, where cycling modal share remained unchanged at around $1 \%$.

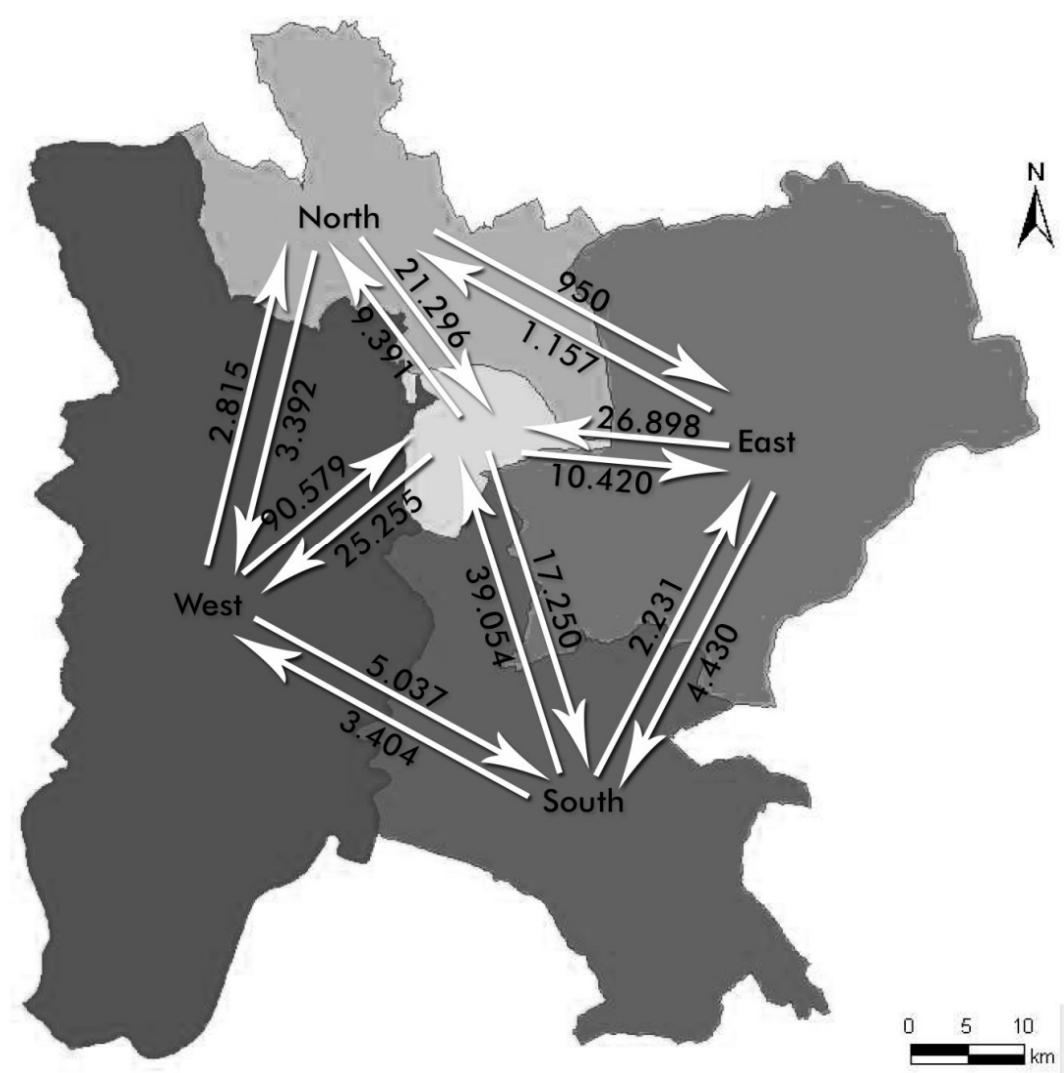

Figure 2: Map of the Metropolitan Area of Seville and total number of daily trips (return trips excluded) between the different sub-zones of the Metropolitan Area of Seville. Source: Consorcio de Transportes del Área de Sevilla (CTAS). Mobility survey, 2007. 
The Regional Government is currently making efforts to promote utilitarian cycling in the main metropolitan areas of Andalusia, including the Metropolitan Area of Seville [25]. However, whereas most distances inside the city are appropriate for cycling, average distances are much longer in the Metropolitan Region, making bicycle-PT links crucial for such policy. In addition, as discussed below, some good practices are being developed in this direction, whose success seems to indicate a good social acceptance of this policy.

Figure 2 shows a schematic map of the Metropolitan Area of Seville along with the daily trips between the different sub-areas. As can be seen, the city of Seville plays a central role in metropolitan mobility, being the most important trip attractor in the area. According to the 2007 mobility survey, participation of PT in metropolitan mobility was relatively low in 2007: $18 \%$ of all trips shown in Fig. 2. Such trips have recently increased due to the opening of an LRT line to an estimated $29 \%$. These trips are divided almost equally between the network of suburban trains, the LRT line and suburban buses. Most of them are connections between Seville and the surrounding metropolitan area, due to the radial structure of the network.

Table 1: Daily combined bicycle and rail trips in the Metropolitan Area of Seville. Trips in suburban trains are split into trips internal to Seville and other trips. Data compiled by authors from surveys made on commuter rail (2009) and LRT (2014) by the operators.

\begin{tabular}{|l|r|r|r|r|}
\hline \multirow{2}{*}{} & \multicolumn{2}{|c|}{ Commuter rail } & \multicolumn{1}{c|}{ LRT } & \multicolumn{1}{c|}{ All trains } \\
\cline { 2 - 5 } & \multicolumn{1}{|c|}{ Internal } & Other trips & \multicolumn{1}{c|}{ All trips } & \multicolumn{1}{c|}{ All trips } \\
\hline Number of trips & 369 & 789 & 1,278 & 2,436 \\
\hline Percentage & $15.1 \%$ & $32.4 \%$ & $52.5 \%$ & $100.0 \%$ \\
\hline
\end{tabular}

Table 1 shows an overview of combined bicycle and rail trips in the Metropolitan Area of Seville. The data in Table 1 are from surveys conducted by the operators of commuter rail and light rail in 2009 and 2013 respectively, which were processed by the authors in order to extract the relevant information. The combined bike and PT trips are approximately $3.6 \%$ of the total daily trips on rail modes. Intermodality between bicycles and commuter rail was already analysed in [6]. Combined trips represent $4 \%$ of these journeys. Most of them involved bringing the bike on board or using the city public bike scheme. The analysis of combined bicycle-LRT trips also shows a high percentage of bike-on-board trips. Bringing bikes on board, however, creates problems at rush hours, and rail companies have recently established restrictions during peak hours. Bringing bikes on board in metropolitan buses is usually forbidden. Moreover, no front or rear bike-racks are provided by bus companies, mainly for safety reasons. Therefore, it is becoming increasingly clear that, in order to 
further develop bicycle-PT intermodality, it will be necessary to shift to bikeand-ride solutions, as has been done in most leading cycling countries [11, 12].

For this reason, the metropolitan transit authority, the Consorcio de Transporte del Área de Sevilla (CTAS), has recently installed 960 bike racks outside bus and LRT stations in the surrounding metropolitan area. This programme, however, has not been very successful, probably due to the fact that users fear their bicycles will be stolen. More recently, additional bicycle racks have been installed inside some LRT stations as a pilot project. Only three months after their installation their success is apparent, which shows that enclosing or protecting the bike parking areas is crucial for the success of such infrastructure, at least during the first steps of its implementation.

Even more conclusive for the development of this project has been the success of the Bus+Bici project, developed by the CTAS in the city's main metropolitan coach terminal [26]. It is a 180-bicycle loan project, similar to the Dutch OV-fiets [13], which allows for the use of bikes for free during the whole day to all users of the station, upon signing a short contract. The project has been very successful, with more than 200 loans per day at a cost of less than $1 €$ per bicycle trip (less than $3 €$ per bicycle loan) including personnel, maintenance and depreciation costs (CTAS, personal communication).

In summary, the analysis of the present status of bicycle-TP intermodality for metropolitan trips in the Area of Seville shows a very underdeveloped intermodality, based on bringing bikes aboard TP vehicles. It also shows a quite good acceptance from TP users of indoor bicycle loan and bicycle parking services at TP stations. In fact, a survey made by the authors among the users of the Bus+Bici service has shown that only a $5 \%$ of them use bicycles as an access mode to the bus stations. However, a $38 \%$ of them declared they would use bikes if there were an appropriate parking infrastructure at the bus station. This percentage rises to $46 \%$ for respondents living farther than 300 from the bus station, which usually considered the threshold for walking access to bus stops [1]. Therefore, lack of parking and bicycle loan infrastructures at PT stations seem to be a main reason for the aforementioned underdevelopment of bicycleTP intermodality.
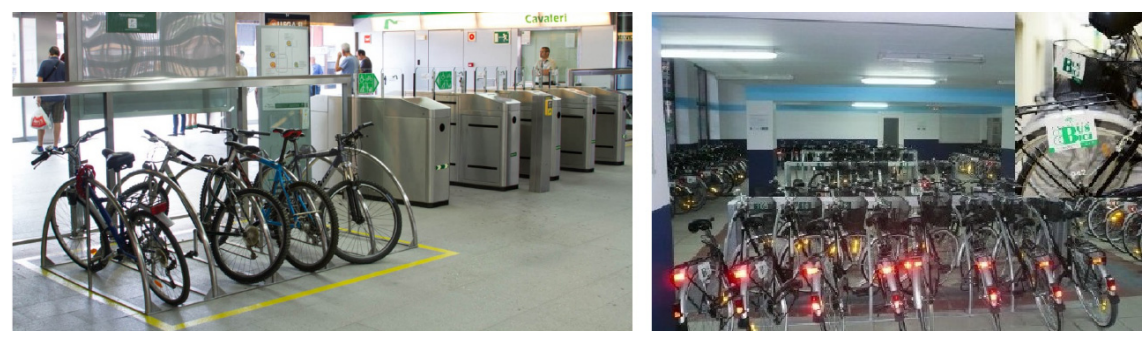

Figure 3: Bike parking inside a LRT station (left) and bicycles from the Bus+Bici project (right). In the inset, a detail with the project logo. 


\section{Methodology and results}

The facts reported in Section 2 suggest that there is some demand for indoor bicycle parking and bicycle loan infrastructures at PT stations. In this section we will develop and apply a GIS based methodology for the estimation of the potential market and demand for such services. The first step towards the determination of the potential market for bicycle-TP intermodality is the determination of the cycling catchment areas of PT stations. Then, the potential market of such intermodal trips is determined as the total number of trips made by the population living in these catchment areas that could be made by a bicycle-TP intermodal chain. Finally, the potential demand is determined as a function of the actual penetration of cycling in the modal share.

As a first approximation for the catchment areas we have considered the area within a radius of $3 \mathrm{~km}$ (Euclidean distance) around the station [19]. This estimate is in qualitative agreement with other estimates that can be found in the literature $[1,10,12]$. However, it is well known that hills can be a deterrent to cycling. Broach et al. have found that the typical utilitarian cyclist will travel $27 \%$ farther to avoid each $1 \%$ of additional upslope [27, 28]. According this formula, for a $3 \%$ slope the average cyclist will make a detour two times longer than the direct route, with an exponential growth of the length of this detour for higher slopes. Therefore, a 3\% slope has been chosen as the limit for comfortable cycling, and zones separated from the PT station by steeper slopes were excluded from the catchment areas. Needless to say, this hypothesis acts as an input for our calculations, which could be changed by other more accurate estimates if appropriate.

In addition to slopes, natural and artificial obstacles, such as rivers or high capacity transport infrastructures, may act as insurmountable limits for cycling. These additional limits have also been taken into account for the determination of the catchment areas.

Another important limiting factor for the effective catchment areas of PT stations is the accessibility of such stations for cyclists [11]. Accessibility implies the existence of the appropriate cycling infrastructure, such as cycle paths, connecting with these stations. As mentioned before, this infrastructure is already in place in the city of Seville. In the surrounding metropolitan area, it is expected to be built in parallel to the project [25]. Accordingly, no additional corrections have been considered in relation to the accessibility of PT stations.

All of this information was included in a Geographic Information System (GIS) in order to determine the catchment areas of high capacity PT stations, mainly commuter trains and LRT. As could be expected, there is a high degree of overlapping between the catchment areas of these PT stations, mainly in the central area of the conurbation, because they were designed to be accessed on foot. Therefore, before continuing with the analysis, it is necessary to assign catchment areas to some stations or groups of stations without overlapping. These catchment areas were determined from heuristic considerations: Stations were grouped when there was not any clear criterion for differentiating their catchment areas and/or there was a continuum of populated areas served by 
them. The resulting catchment areas are shown in Fig. 4. The central area is the whole city of Seville, which has been considered as a single area because, as previously mentioned, the entire city of Seville can be considered accessible by bicycle. The remaining areas correspond to other towns and urban developments in the conurbation.

The next step was the determination of the population inside each catchment area. This population was determined using the population grid entitled "Spatial Distribution of Population in Andalusia", published by the Institute of Statistics and Cartography of Andalusia (Spain) [29], which provides information on the total population, based on a division of Andalusia into homogeneous cells of $250 \times 250$ metres. These calculations give an overall population within cycling distance of the stations of Fig. 4 of 1,019,996 people, $67.2 \%$ of the total population of the Metropolitan Area.

Once the population within cycling distance of each station or group of stations shown in Fig. 4 had been determined, the potential market for bicycleTP intermodality was estimated as the total number of trips made to Seville by this population in a typical working day. Only trips to Seville have been considered because, as mentioned before, the PT network has a radial structure, and other metropolitan trips are few (see Fig. 2) and difficult to be made by public transport.

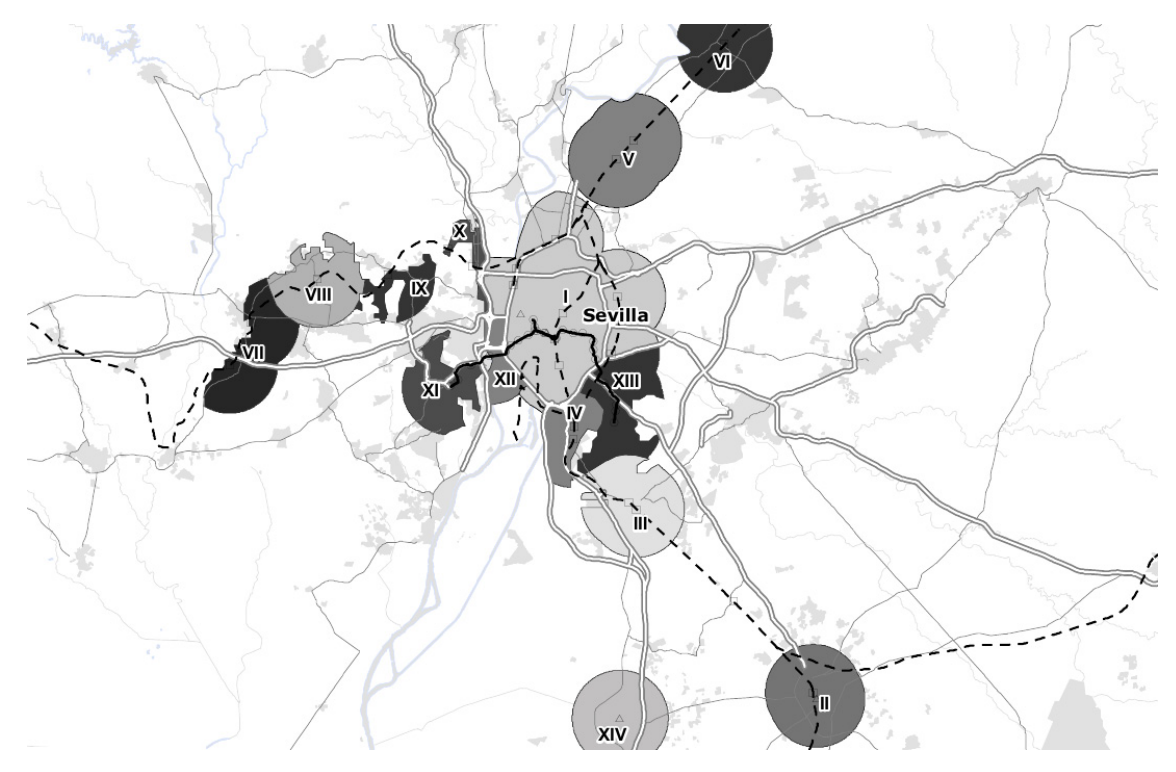

Figure 4: Catchment areas for the different PT stations and groups of stations (see Tables 2 and 3). The LRT line (solid line) and the commuter rail lines (dashed lines) also are shown. 
Table 2: Population within a cycling distance of the stations in the surrounding metropolitan area of Seville, trip coefficients, potential market, and expected demand for Bicycle-TP intermodal trips with origin in each area, for the different scenarios considered in the text. In parenthesis, the number of PT stations inside each area if more than one.

\begin{tabular}{|l|r|r|r|r|r|r|}
\hline \multicolumn{1}{|c|}{ Stations } & \multicolumn{1}{|c|}{ Population } & Coefficient & \multicolumn{1}{c|}{ Market } & \multicolumn{3}{|c|}{ Demand } \\
\hline & & & & \multicolumn{1}{c|}{ Opt. } & \multicolumn{1}{c|}{ Int. } & \multicolumn{1}{c|}{ Pes. } \\
\hline II Utrera & 46,061 & 0.17 & 7,830 & 783 & 470 & 78 \\
\hline III Dos Hermanas (2) & 88,648 & 0.19 & 16,843 & 1,684 & 1,011 & 168 \\
\hline IV Bellavista (2) & 16,496 & 0.49 & 8,083 & 808 & 485 & 81 \\
\hline V La Rinconada (2) & 27,173 & 0.26 & 7,065 & 706 & 424 & 71 \\
\hline VI Brenes & 12,863 & 0.13 & 1,672 & 167 & 100 & 17 \\
\hline VII Benacazón (2) & 11,091 & 0.18 & 1,996 & 200 & 120 & 20 \\
\hline VIII Villanueva (2) & 15,977 & 0.21 & 3,355 & 336 & 201 & 34 \\
\hline IX Salteras & 10,166 & 0.31 & 3,151 & 315 & 189 & 32 \\
\hline X Camas & 16,787 & 1.19 & 19,977 & 1,998 & 1,199 & 200 \\
\hline XI Aljarafe Este (3) & 63,663 & 0.40 & 25,465 & 2,547 & 1,528 & 255 \\
\hline XII San Juan Bajo & 1,702 & 0.16 & 272 & 27 & 16 & 3 \\
\hline XIII Quintos (4) & 20,661 & 0.33 & 6,818 & 682 & 409 & 68 \\
\hline XIV Los Palacios (bus) & 35,266 & 0.13 & 4,585 & 458 & 275 & 46 \\
\hline TOTAL & 366,554 & & 107,113 & 10,711 & 6,427 & 1,071 \\
\hline
\end{tabular}

The total number of such trips was determined from the 2007 Mobility Survey made by the CTAS, which gives information about the origin and purpose of all trips made in the Metropolitan Area. Unfortunately, respondents to this survey were classified according the census tracts, which are different and substantially bigger than the aforementioned cells of the population grid. Consequently, discrepancies may appear between the population determined by using the census tracts and the population grid. Thus, in order to determine the potential market of trips, the ratio between the total number of trips to Seville and the population for all of the census tracts totally or partially included in each catchment area of Fig. 4 was determined. This "trip coefficient" was then multiplied by the population determined by using the population grid in order to obtain the potential market for trips.

Finally, to assess the expected demand for bicycle-PT intermodality it has been assumed that, if appropriate infrastructure is provided, the percentage of trips to Seville made by an intermodal Bicycle-PT chain will be similar to the total percentage of trips made by bike in each catchment area [19].

In order to evaluate this demand, three scenarios were considered. Firstly, there is the pessimistic scenario, in which the cycling modal share of the surrounding metropolitan area remains unchanged at 1\% (see above). Secondly, there is the intermediate scenario, which assumes a $6 \%$ bicycle modal share in the surrounding metropolitan area, similar to the present situation in Seville. And finally, there is the optimistic scenario, which assumes that the bicycle reaches a $10 \%$ of the modal share, according to the forecasts of the Andalusian Bicycle Master Plan [14]. These percentages are applied to the potential market in order to estimate the demand. Needless to say, these hypotheses are specific to the 
present analysis and would change if the proposed methodology were applied to other geographic regions.

The results of these calculations are shown in Table 2. The results in the last three columns show the expected combined bicycle and PT trips made by the population of the surrounding metropolitan area towards Seville in the three considered scenarios.

The same methodology can be applied to the determination of the expected combined bicycle and PT trips made by the population of Seville towards the peripheral PT stations. In fact, if the coefficients in Table 2 are substituted by the quotients between the trips towards each peripheral area made by people living in Seville, divided by the population of these areas, calculations give the expected combined bicycle and PT trips made by the population living in Sevilla towards each area in the surrounding metropolitan area. The results of these calculations are shown in Table 3 for the different scenarios.

The results of tables 2 and 3 can be used as a guide for the implementation of bicycle parking areas and other infrastructures, such as bicycle loan services at TP stations. For instance, the results of the last column of Table 2 (pessimistic scenario) can be interpreted as an estimation of the present demand for bike parking spaces at peripheral PT stations. This demand is now mainly satisfied by bringing the bike aboard. The results of Table 3 can be interpreted as an estimation of the demand of services aimed at promoting the bicycle as an egress mode at TP stations in the surrounding metropolitan area. These services may include bike loan services, public bike-sharing stations or simply spaces in parking areas for bicycles that "sleep" at the station, ready to be used each morning by their owners [11].

Table 3: Population within cycling distance of the stations of the surrounding metropolitan area of Seville, trip coefficients, potential market, and expected demand for bicycle-TP intermodal trips with origin in Seville, for the different scenarios considered in the text.

\begin{tabular}{|l|r|r|r|r|r|r|}
\hline \multicolumn{1}{|c|}{ Stations } & \multicolumn{1}{c|}{ Population } & \multicolumn{1}{c|}{ Coefficient } & \multicolumn{1}{c|}{ Market } & \multicolumn{3}{c|}{ Demand } \\
\hline & & & & \multicolumn{1}{c|}{ Opt. } & \multicolumn{1}{c|}{ Int. } & \multicolumn{1}{c|}{ Pes. } \\
\hline II Utrera & 46,061 & 0.03 & 1,382 & 138 & 83 & 14 \\
\hline III Dos Hermanas (2) & 88,648 & 0.06 & 5,319 & 532 & 319 & 53 \\
\hline IV Bellavista (2) & 16,496 & 0.98 & 16,166 & 1,617 & 970 & 162 \\
\hline V La Rinconada (2) & 27,173 & 0.18 & 4,891 & 489 & 293 & 49 \\
\hline VI Brenes & 12,863 & 0.02 & 257 & 26 & 15 & 3 \\
\hline VII Benacazón (2) & 11,091 & 0.04 & 444 & 44 & 27 & 4 \\
\hline VIII Villanueva (2) & 15,977 & 0.04 & 639 & 64 & 38 & 6 \\
\hline IX Salteras & 10,166 & 0.03 & 305 & 30 & 18 & 3 \\
\hline X Camas & 16,787 & 0.09 & 1,511 & 151 & 91 & 15 \\
\hline XI Aljarafe Este (3) & 63,663 & 0.08 & 5,093 & 509 & 306 & 51 \\
\hline XII San Juan Bajo & 1,702 & 0.30 & 511 & 51 & 31 & 5 \\
\hline XIII Quintos (4) & 20,661 & 0.10 & 2,066 & 207 & 124 & 21 \\
\hline XIV Los Palacios (bus) & 35,266 & 0.01 & 353 & 35 & 21 & 4 \\
\hline TOTAL & 366,554 & & 38,936 & 3,894 & 2,336 & 389 \\
\hline
\end{tabular}


Overall estimates for all the PT stations in Seville can also be made from the results of the last rows of tables 2 and 3. For instance, the results of the last row of Table 3 show the overall demand of bicycle parking at PT stations in Seville, although more research is needed in order to reach specific estimates for the different PT stations in the city. The same can be said from peripheral TP stations when they share the same catchment area. In this case, other considerations different from demand, such as available space at stations or accessibility, may be taken into account for infrastructure planning.

\section{Conclusions}

Improving links between bicycles and public transport is an essential part of any policy aimed at improving the sustainability of transport. In this paper, a methodology for the evaluation of the demand for bicycle-TP combined trips in metropolitan areas has been presented. This methodology is based on the determination of the main catchment areas for TP stations or groups of stations and of the population living in these areas by using a GIS. The market for bicycle-TP combined trips at each catchment area is then determined by using mobility surveys. Finally, the expected demand is evaluated for different scenarios of penetration of utilitarian cycling in the mobility market. The methodology differentiates between using the bicycle as an access or an egress mode to public transport. Therefore, it can be used for the planning of both kind of infrastructures.

This methodology has been applied to the evaluation of the demand for bicycle-TP intermodality in the Metropolitan Area of Seville. This city has recently developed a very successful cycling infrastructure, mainly based on a network of bicycle paths connecting the principal trips attractors in the city with residential areas. Improving the links between bicycles and public transport may help to go further in bike promotion, thus connecting the city and the periphery through a fully sustainable intermodal chain.

\section{Acknowledgements}

This work has been supported by the Agencia de Obra Pública de Andalucía Junta de Andalucía under Project G-GI3001/IDID. We would also like to thank the Consorcio de Transportes del Área de Sevilla for kindly providing many data for this analysis, and to Mr. James Langford for proofreading the original.

\section{References}

[1] Dekoster, J., Schollaert U. Cycling: the way ahead for towns and cities. http://ec.europa.eu/environment/archives/cycling/cycling_en.pdf

[2] National policies to promote cycling. European Conference of Ministers of Transport (EUCMT), Lubjana 2004. OECD. Online. http://international transportforum.org/pub/pdf/04Cycling.pdf 
[3] Pucher, J. Dill, J. \& Handy, S., Infrastructure, programs, and policies to increase bicycling: An international review Preventive Medicine, 50, pp. S106-S125, 2010.

[4] The Copenhagenize index 2013 of bicycle friendly cities. Copenhagenize Design Co. http://copenhagenize.eu/index/about.html

[5] TEMS - The EPOMM Modal Split Tool, European Platform on Mobility Management. Online: http://epomm.eu/tems/index.phtml

[6] Marqués, R., Hernández-Herrador, V., Calvo-Salazar, M., Sevilla: A successful experience of bicycle promotion in a Mediterranean context. The Sustainable City IX. Urban Regeneration and Sustainability, eds. N. Marchettini, C.A. Brebbia, R. Pulselli \& S. Bastianoni, WIT Press, Vol. 1, pp. 769-781, 2014. http://www.witpress.com/elibrary/wit-transactions-onecology-and-the-environment/191/29556

[7] Hegger, R. (2007). Public transport and cycling: living apart or together? Public Transport International, 56 (2), pp. 38-41, 2007.

[8] Bachand-Marleau, J., Larsen, J., \& El-Geneidy, A.M. Much anticipated marriage of cycling and transit. Transportation Research Record: Journal of the Transportation Research Board, 2247 (1), pp. 109-117, 2011.

[9] Brons, M., Givoni, M., \& Rietveld, P. Access to railway stations and its potential in increasing rail use. Transportation Research Part A: Policy and Practice, 43 (2), pp. 136-149, 2009.

[10] Rietveld, P. The accessibility of railway stations: the role of the bicycle in The Netherlands. Transportation Research Part D: Transport and Environment, 5 (1), pp. 71-75, 2000.

[11] Pucher, J. \& Buehler R., Integration of Cycling with Public Transportation (Chapter 8). City Cycling eds. J. Pucher and R. Buehler MIT Press, pp. 157-182, 2012.

[12] Martens, K., The bicycle as a feedering mode: experiences from three European countries Transportation Research Part D, 9, pp. 281-294, 2004.

[13] Martens, K., Promoting bike-and-ride: The Dutch experience. Transportation Research Part A, 41, pp. 326-338, 2007.

[14] Shaheen, S.A., Zhang, H., Martin, E., \& Guzman, S., China's Hangzhou Public Bicycle: Understanding Early Adoption and Behavioral Response to Bikesharing. Transportation Research Record: Journal of the Transportation Research Board, 2247 (1), pp. 33-41, 2011.

[15] Krizek, K.J., \& Stonebraker, E.W. Bicycling and Transit. Transportation Research Record: Journal of the Transportation Research Board, 2144 (1), pp. 161-167, 2010.

[16] Krygsman, S., \& Dijst, M. Multimodal trips in the Netherlands: microlevel individual attributes and residential context. Transportation Research Record: Journal of the Transportation Research Board, 1753 (1), pp. 1119, 2001.

[17] Krygsman, S., Dijst, M., \& Arentze, T. Multimodal public transport: an analysis of travel time elements and the interconnectivity ratio. Transport Policy, 11 (3), pp. 265-275, 2004. 
[18] Debrezion, G., Pels, E., \& Rietveld, P. Modelling the joint access mode and railway station choice. Transportation Research Part E: logistics and transportation review, 45 (1), pp. 270-283, 2009.

[19] Adjei, E. (2010). Multi-modal urban transport: Integrating non-motorized and bus transport (Thesis submitted to the International Institute for Geoinformation Science and Earth Observation). Online: http://www.itc.nl/library/papers_2010/msc/upm/adjei.pdf

[20] Rybarczyk, G., \& Wu, C. Bicycle facility planning using GIS and multicriteria decision analysis. Applied Geography, 30 (2), pp. 282-293, 2010.

[21] Aultman-Hall, L., Hall, F.L., \& Baetz, B.B. Analysis of bicycle commuter routes using geographic information systems: implications for bicycle planning. Transportation Research Record: Journal of the Transportation Research Board, 1578 (1), pp. 102-110, 1997.

[22] O'Sullivan, D., Morrison, A., \& Shearer, J. Using desktop GIS for the investigation of accessibility by public transport: an isochrone approach. International Journal of Geographical Information Science, 14 (1), pp. 85104, 2000.

[23] Marqués, R. (chair), Calvo-Salazar, M., García-Cebrián, J.A., HernándezHerrador, V., del Moral, L. Estudio sobre el uso de la bicicleta en Sevilla, 2011. Sistema Integral de la Bicicleta de la Universidad de Sevilla (SIBUS), 2012. Online. http://bicicletas.us.es/Sevilla2011.pdf

[24] Marqués, R. (chair), Calvo-Salazar, M., Hernández-Herrador, Estudio sobre el uso de la bicicleta en Sevilla, 2013. Sistema Integral de la Bicicleta de la Universidad de Sevilla (SIBUS), 2014. Online. http://bicicletas.us.es/Sevilla2013.pdf

[25] Plan Andaluz de la Bicicleta. Consejería de Fomento, Junta de Andalucía http://www.aopandalucia.es/planandaluzdelabicicleta/

[26] CTAS. Servicio Bus+Bici. Online: http://www.consorciotransportessevilla.com//proyectos/busbici/busbici.php

[27] Broach, J., Gliebe, J., \& Dill, J., Development of a multi-class bicyclist route choice model using revealed preference data. Presented at the 12th International Conference on Travel Behavior Research, Jaipur, India, Dec. 2009.

http://pdxscholar.library.pdx.edu/cgi/viewcontent.cgi?article=1020\&conte $\mathrm{xt}=$ usp_fac

[28] Aultman-Hall, L., Dowds, J., \& Lee, B. H. (2012). Innovative Data Collection for Pedestrians, Bicycles, and Other Non-Motor Vehicle Modes. TR News-Transportation Research Board, 280, pp. 8-15. 2012

[29] Instituto de Estadística y Cartografía de Andalucía (IECA). Online: http://www.juntadeandalucia.es/institutodeestadisticaycartografia/bd/GRI Dvisor/ 